\title{
Challenges and Opportunities in the Management of Electoral Conflicts in Nairobi County, Kenya
}

\author{
Dorothy Muthoni Mutemi \\ Post-Graduate Candidate, \\ Department of Peace and Conflict Studies, \\ Masinde Muliro University of Science and \\ Technology, Kenya
}

\begin{abstract}
This study sought to examine the challenges and opportunities in the management of electoral conflicts in Nairobi County, Kenya. The study used a descriptive research design. Questionnaires, interview guides, and FGDs were used to collect primary data whereas secondary data was gathered from journals and reports. Quantitative data was analysed by SPSS version 22 while qualitative data was analysed through coding, verbatim and thematic organization. The study found out that the major challenges to the peacebuilding process include suspicion, lack of trust, ethnicity, corruption within the electoral body, misinterpreting the constitution, and rampant unemployment across the country. From the findings and the expansive literature review, peacebuilding efforts can be boosted by training security forces, conducting voter awareness campaigns, developing citizens trust, conducting civic education, training and planning, and monitoring and watchdog initiatives. The findings and recommendations of this study will benefit scholars in the field of peacebuilding and related fields, policy makers, and other stakeholders in peacebuilding and conflict management.
\end{abstract}

Keywords:- Challenges, Opportunities, Management, Electoral Conflict.

\section{INTRODUCTION}

Peace building includes post-conflict initiatives to rebuild societies and forestall a return to violence and conflict situations (Austin, Fischer, \& Wils, 2003). However, the process of peace building is rife with complexities and as a comprehensive concept, it encompasses, generates, and sustains the full array of processes, approaches, and stages needed to transform conflict towards more sustainable, peaceful relationships. It simultaneously seeks to enhance relationships between parties and to change the structural conditions that generate conflict (Kalvvas, 2006).

Given the nascent nature of the peacebuilding field, there are numerous complexities and flaws in the design frameworks that contribute to the inability of sustainable peace relations to persevere" (Golan \& Zahira, 2005). About half of all peace support operations (including both peacekeeping and more expansive peacebuilding operations) fail after around five years. Moreover, the

\author{
Professor Kennedy Onkware \\ Dean, Department of Emergency Management Studies, \\ School of Disaster Management and \\ Humanitarian Assistance, \\ Masinde Muliro University of Science and \\ Technology, Kenya
}

presence of leaders, neighboring countries, and factions opposed to peace are often willing to use violence to undermine the rebuilding process. These 'defectors', also known as 'spoilers,' will require specific attention to mitigate the chances that these factors will contribute to the breakdown of such an extremely fragile process. Given the inability to control these destabilizing spoilers there are numerous breakdowns in the peace process that effectively contribute to the low success rate of peacebuilding operations (Hart, 2006).

Each aspect within the peacebuilding framework can only be successful when supported by actions to improve and rebuild individual dimensions of the others. For example, security, often a top priority for peacebuilding, is susceptible to breakdown from an impaired governance framework and poor policy decisions (Heldi, 2008). If development issues are not addressed, socioeconomic inequalities can result in a relapse to violence and a breakdown of security; if groups are not reconciled, tensions will unravel the social fabric required to sustain peace. Hence, each is part of the broader peacebuilding process and cannot be disentangled from the others (Hilson, 2006).

The process of peacebuilding calls for new attitudes and practices: those that are flexible, consultative and collaborative and that operate from a contextual understanding of the root causes of conflict. For divided societies, majority rule is not only undemocratic but also dangerous (Berwind, 2012). Peacebuilding designs requires the development of institutional capacities such as the judiciary, the electoral system, and other agencies that work to advance policy reforms, enhance transparency, and increase representation and accountability.

The role of an election during peacebuilding is significant for numerous reasons. Non-violent and successful political transitions become a critical test to determine whether new relationships can develop among former adversaries - the party that loses needs tangible, symbolic and even material benefits from their participation in the new governance system in order for it to be embraced by those who do not gain full political power (Faria, 2011). 
Also critical to effective governance is the role of the judiciary. The stability of these systems, however, cannot be achieved without the participation of former adversaries in the democratic political processes and socio-economic reforms (Barakat, 2005). Strengthening the institutions of governance then is critical to ensuring the establishment of democracy which in turn is essential if future conflicts are to be avoided (Flynn, 2002). Mechanisms for pursuing reconciliation include "dialogue between former adversaries, story sharing, compiling records of human rights violations and Truth Commissions" (Ghai \& Regan, 2006). These actions also serve to deter "former abusers and provide a lasting legacy and reminder of the atrocities that have occurred (Gichuru, 2014).

In Kenya, insufficient or ineffective conflict analysis tools led to repeated electoral violence, although to a minimum level, in 2013 and in 2017 after the intense violence in 2007. A look at current peacebuilding in Kenya reveals some key problems. First, at local levels the government response to displacement remains largely within the pre-election security paradigm, entailing the construction of more police posts and involving the security apparatus in resettlement, despite ample evidence that many members of the provincial administration and police played into the violence. Second, peacebuilding often fails to address cultural practices and narratives (on all sides) that can aggravate tensions and interethnic relations. Lastly, while some efforts attempt to leverage economic reconstruction and development assistance to deepen interethnic linkages and cooperation, in practice, peacebuilding continues to be perceived and hence funded and implemented as a separate activity from development.

\section{LITERATURE REVIEW}

There are several factors that can affect conflicts around election; however, one of the leading factors remains to be the degree to which political groups trust EMB. EMB transparency and credibility can give an assurance on the peaceful election, even if in the presence of crisis and irregularities (Annette \& Dawn, 2017). Back in 2006 and 2007 in Bangladesh, there was a severe case reported concerning political leaders. It was published by the EVER team program that some political leaders in various constituencies did not want to be "caught" using violence but encouraged supporters to engage in violence or any other violent activities (Taylor \& Scott, 2017). It is possible that the intervention which was going on at the local level could exploit the gains retrieved by the EVER team.

From Eastern Europe to Nicaragua and South Africa to Sudan, peace committees have served to foster locallevel peace during times of turbulent transition when the authority of local governments is perceived to be illegitimate or the structures of local democracy are in flux (Fjelde \& Kristine, 2016).In Kenya, one can encounter the impact of low trust in the state institution and EMB. In the 2007 election, the election process including the casting of ballots, but providing platform for irregularities (both alleged and real) and bad communication strategy gave a hand to fuel violence (Annette \& Dawn, 2017).

Another challenge that thwarts peacebuilding efforts during elections is lack of proper training for security forces. With the exception of certain post-conflict or ongoing conflict environments, the burden of day-to-day electoral security falls on domestic police services (Bekoe \& Stephanie, 2017). In many transitional countries, the police force already faces enormous challenges in resources and capacities, and may not have the trust of the public, certain communities or political groups. Competence and credibility gaps cannot be filled in the short time usually available for training security forces in preparation for elections (Bekoe \& Stephanie, 2017). In Kenya, police have been known to use excessive force to manage riots and demonstrations. This was evident in 2007 in Kisumu when the police shot at rioters. The same was also experienced in 2013 and 2017 when demonstrators were beaten, shot at, and even killed (European Union, 2018).

The peace and reconciliatory building strategists ought to view their primary capacity as planning struggle reactions (Annette and Day break, 2017). As such, an exhaustive and comprehensive security plan should set out principles of commitment, drive organizations and different conventions that incorporate activities for prevention just as for moderation and the executives of contention. Poststruggle nations or those encountering outfitted clashes will, obviously, require altogether different reactions than progressively stable conditions (Annette and Dawn, 2017). To guarantee satisfactory usage of security plans, planning ought to be done ahead of schedule (as a component of contention investigation and counteractive action) and ought to illuminate preparing programs, for both EMB staff and included security powers.

The justice system should always be prepared to react to electoral violations and violations that may fall under criminal or common law, and for the particular methodology required for settling issues documented under the appointive protests instrument (Burchard, 2015). In certain nations, for example, Guatemala, an exceptional team is made to manage investigations and arraignment of constituent brutality (Annette and Dawn, 2017). Difficulties with this incorporate the capacity to effectively distinguish electoral violence and the general dimension of trust between the organization, the general population and ideological groups. The key is to distinguish shortcomings in the present framework and move to address them in the best way for the nation setting, between decisions, before violence ejects.

It is important that the public trusts and understands the results process and how the results translate into seats or winners. That is, it is important to educate voters - in advance - on the process, as well as minimum votes needed, seat allocation, and run-off requirements among others (Fischer, 2012). For instance, tensions rose swiftly in East Timor in 2007 when the use of a complicated formula for seat allocation led to coalition-building that did not 
seem to properly reward the party that won the most votes. An extensive education campaign organized by IFES and other partners was critical in reducing tensions, but such post-Election Day campaigns do not always work (UNDP, 2017).

\section{METHODOLOGY}

This study used a descriptive survey design based on mixed methods of data collection and analysis. According to Creswell (2014), descriptive design enables the researcher to formulate crucial knowledge principles as well as solutions to the underlying problems. Going by what Kombo and Tromp (2007) postulates, this design is also appropriate for this study because it will help to gather information on the current phenomenon and generate valid conclusions from the data collected. To effectively achieve this objective, the researcher administered both interviews and questionnaires to gather as much information as possible.

This study was conducted in Nairobi County of Kenya because it is a hotspot to various forms of conflict, especially electoral violence. The study focused on household heads from the populous areas of Nairobi County, peace organizations, area leaders, relevant governmental institutions, and church leaders. In total, there were 289 questionnaires distributed among the household heads, 19 interviews conducted, and 10 FGDs. The study used systematic sampling technique to select the households. Chiefs, assistant chiefs, senior police officers, local peace organizations leaders, international peace organizations leaders, and senior disaster management staff, were selected using purposive sampling. Lastly, snowballing was used to select religious leaders.

This study measured the validity of the instrument using content and factorial validity. The Cronbach's alpha coefficient for internal consistency of the research instruments was validated at $\alpha=0.84$. According to Mugenda \& Mugenda (2009), instruments are considered to be acceptable and reliable if $\alpha \geq 0.8$ hence $\alpha \geq 0.84$ was good and reliable for the study. Reliability was tested using the test-retest correlation, which normally provides a sign of stability in the long run. The instrument scored Cronbach's alpha $(\alpha)$ value $\alpha \geq 0.74$, therefore, was considered reliable.

The International Business Machines (IBM) Statistical Package for Social Sciences (version 22) was used to analyze quantitative data. Under SPSS, both descriptive and inferential statistics were used and data presented in frequencies, tabulation and percentage. Qualitative data was coded and analysed thematically and in verbatim, which helped to highlight the emerging themes. All the ethical requirements were considered, including consent from the respondents and permission from the relevant institutions.

\section{RESULTS}

The study found out that one of the major challenges to the peacebuilding initiatives has been suspicion. Whenever measures are initiated to help restore and ensure peace, some people always treat them with suspicion, not sure if they will work and if they will take care of their interests. Closely related to suspicion is lack of trust. According to one respondent, "Mwai Kibaki was forced to share power with Raila Odinga...two ideologies coming together, one wanting to pull in one direction and the other wanting to pull in a different direction."

From the study, ethnicity was also found to be another challenge to peacebuilding efforts. When asked to respond to what factors account for the continued rise in the frequency and intensity of electoral conflict in Kenya even after the promulgation of the new constitution, one participant stated, "Quite a number of actors. One is too much affiliation to our ethnicities, such that even with the superior laws in place our ethnicities appear to be more important than law. There is a lot of allegiance to ethnicities and regional politics."

Corruption within the Electoral Body was also found to be another challenge affecting peacebuilding strategies. Most respondents agreed that corruption is the biggest factor as electoral laws are flaunted with impunity in this country. As one respondent stated, "People steal money and use that money for elections. Even though the electoral laws for bids, voter bribery, and people buy votes...."

The current study also found that misinterpreting some sections of the constitution could be a major challenge to attaining long-lasting peace in Kenya. Besides, failing to implement some of the sections proved a challenge to use the constitution as a peace building tool. When asked if the constitution does have any anomalies that are making it ineffective as post-conflict peacebuilding strategy, one respondent answered, "It does not have anomalies but the interpretation of some sections could be a problem.."

Rampant unemployment across the country was also found to be another challenge affecting peacebuilding initiatives. With a good percentage of youths jobless, it is easy to manipulate them, especially during electioneering period. As stated by one of the respondents, "What causes violence is not just the acts of wars. This country has a big bunch of unemployed youth, who are easily paid by politicians to cause mayhem.."

To find out what can be done to improve peacebuilding efforts in Kenya, the researcher sought to know if training security forces can help prevent electoral conflict and build peace. From the findings, $18.4 \%$ of the respondents strongly disagreed with this statement, $17.1 \%$ somehow disagreed, and $15 \%$ disagreed. On the other hand, $16.8 \%$ of the respondents agreed, $16.2 \%$ somehow agreed, and $9.7 \%$ strongly agreed. A cumulative $50.5 \%$ of the respondents disagreed that training security forces can help 
prevent electoral conflict and build peace. However, $42.7 \%$ of the respondents felt that training security forces could help prevent electoral conflict and build peace.

To further find out measures that can be used to improve peacebuilding efforts, the study sought to know if conducting voter awareness campaigns can help prevent electoral violence and build peace. From the findings, 5.9\% strongly disagreed, $7.2 \%$ somehow disagreed, and $3.4 \%$ disagreed. On the other hand, $31.5 \%$ of the respondents agreed that conducting voter awareness campaigns can help prevent electoral violence and build peace. Cumulatively, $80.7 \%$ of the respondents felt that conducting voter awareness can help prevent electoral violence and build peace.

The study also sought to find out if developing citizen trust is an effective way of building perpetual peace. From the findings, $8.1 \%$ of the respondents strongly disagreed, $7.8 \%$ somehow disagreed and $3.7 \%$ disagreed. On the other hand, $32.4 \%$ of the respondents agreed that developing citizen trust is an effective way of building everlasting peace, $22.1 \%$ somehow agreed and $21.8 \%$ strongly agreed. Cumulatively, $76.3 \%$ of the respondents felt that developing citizen trust is an effective way of building perpetual peace.

The research also sought to know how the Building Bridges Initiative can be used as a peacebuilding strategy. Respondents felt that if done in the right way, the BBI can be used as an effective peace building strategy. As one respondent narrated, "Yes. It is a model that can even be exported to other countries. People fight during these conflicts but if we can foresee that there is going to be conflict then why not get this model, share power, before the fighting..."

\section{DISCUSSION}

While the constitution is considered as an important appendage to the peace building process, lack of conflict resolution structures makes it hard for peace to be attained. The reason Kenya normally experiences post-election violence is because it lacks structures for conflict resolution. People do not trust the courts. Having institutions to address conflict is very important because in politics, there is always going to be conflicts. According to Taylor \& Scott (2017), to have political equilibrium there needs to be systems that address processes the grievances of the people and people are satisfied with it.

In support of the verbatim in the current study, Fodeba and Sahr (2010) found that peace building process in Sierra Leone was not easy to achieve because some party leaders did not believe in the judicial and electoral bodies. They felt that once the agreement had been signed, the incumbents could take advantage of their powers to corrupt systems. From the previous studies, the presence of leaders, neighboring countries, and factions opposed to peace are often willing to use violence to undermine the rebuilding process. These 'defectors', also known as 'spoilers,' will require specific attention to mitigate the chances that these factors will contribute to the breakdown of such an extremely fragile process (Hart, 2006).

In previous studies, Chopra (2008) and Kiplagat (2008) pinpointed ethnicity as a major determinant of peace in Kenya. Although Kenya has approximately 42 ethnicities, only a few groups normally engage in skirmishes because of one reason or another. Due to longstanding enmities and differences among conflicting ethnicities, it becomes a challenge bringing them together to share the same peace ideologies.

Current findings also corroborate Fjelde and Kristine (2016) findings that in Jamaica, where the link between corruption and electoral violence is well known, monitoring and watchdogs have become one avenue for addressing violence. In 2011, Non-governmental actors, including the media, local organizations and political parties, were more recognized for promoting and implementing monitoring and advocacy efforts (Fjelde \& Kristine, 2016).

In Kenya, police normally use excessive force in quelling crowds, especially demonstrators. This is another form of violence, which should be prevented, and it can only be achieved when the security forces learn to use less violent ways of handling crowds. From the previous studies, a number of researchers categorized police brutality as part of electoral violence. Bekoe \& Stephanie (2017), for example found that another challenge that thwarts peacebuilding efforts during elections is lack of proper training for security forces. With the exception of certain post-conflict or on-going conflict environments, the burden of day-to-day electoral security falls on domestic police services (Bekoe \& Stephanie, 2017). In many transitional countries, the police force already faces enormous challenges in resources and capacities, and may not have the trust of the public, certain communities or political groups. This gap in training cooperation is another example of the sector-specific focus (Collier \& Vicente, 2014). However, these challenges could be better addressed through increased cooperation with EMBs.

Through voter awareness campaigns, people are educated on the importance of maintaining peace and the consequences of engaging in violent activities. From the previous studies, voter education is normally conducted mostly among the youths to enlighten them on the importance of peaceful elections. For example, a report by the Commonwealth (2015) shows that civic and voter education helps to empower voters so that they feel a greater stake in the outcome and, more fundamentally, understand how to cast their vote. Through peaceful elections, people can elect leaders of their choice, who will help address their grievances.

It is necessary to create opportunities for youths to understand the importance of peace and desist from being used by politicians. Apart from those in schools, other youths should also be incorporated in different activities to ensure that they are not misused by politicians. Youths 
should be made to understand that politicians have their own selfish interests and do not have the needs of the youths at heart. To fix the perennial electoral violence, civic education is a necessity.

For any peacebuilding strategy to be effective, people must first of all have trust and faith in the ruling systems at that time. When, for example, people are assured that the elections will be free and fair, and that the electoral body will be transparent and accountable, they are less likely to develop the fear that normally comes after elections, thus finding courage not to evacuate their places of residence. When citizens also develop trust with the current systems, they are less likely to plan for any heinous activities because of the faith that the elections will be transparent and not tempered with (Fischer, 2012).

Monitoring and watchdog initiatives, whether initiated by state institutions or civil society organizations, can provide accurate, continuous information on existing/increasing tensions, electoral violence or electoral violations (Fjelde \& Kristine, 2016). They can increase conflict prevention success because they address impunity, secrecy and rumors - problems that often foster electoral conflict in transitional democracies.

Political reconciliation can also be used to strengthen peacebuilding. In Kenya, the Building Bridges Initiative (BBI) was born out of the Raila-Uhuru handshake. As a new initiative, the BBI is linked to the handshake but is a different initiative that needs to be given time. However, some people felt that the handshake should be given more time to see if it is effective in ensuring peace among Kenyans, as it is only a recent development.

\section{CONCLUSION}

From the study, some of the challenges impeding peacebuilding strategies in Nairobi County include suspicion, lack of trust, ethnicity, corruption within the electoral body, misinterpreting the constitution, and rampant unemployment across the country. However, peacebuilding efforts can be boosted by training security forces, conducting voter awareness campaigns, developing citizens trust, conducting civic education, training and planning, and monitoring and watchdog initiatives. These initiatives will help ensure the success of the major peacebuilding strategies.

\section{REFERENCES}

[1]. Annette M. \& Dawn, B. (2017). Elections and peacebuilding. A Kofi Annan Foundation Initiative, Policy Brief no. 4

[2]. Austin, A.., Fischer, M. \& Wils, O. (2003). 'Peace and Conflict Impact Assessment', in Berghof Handbook for Conflict Transformation, Berghof Research Center, Berlin.

[3]. Barakat, 2005
[4]. Bekoe, D. \& Stephanie M. (2017). The Contradictions of Pre-Election Violence." African Studies Review 60(2): 73-92.

[5]. Berwind, D (2012). Women, Gender and Peacebuilding: Do Contributions Add Up?" 2, 1-13.

[6]. Burchard, S. (2015). Electoral Violence in Africa: Causes and Consequences. Boulder, CO:Lynne Reinner.

[7]. Chopra, T. (2008), 'Reconciling Society and the Judiciary in Northern Kenya', Legal Resources Foundation Trust, Nairobi, Kenya, 2008.

[8]. Collier, P. \& Vicente, P. (2014). Votes and Violence: Evidence from a field Experiment in Nigeria. The Economic Journal 124(574): F327-F355.

[9]. Commonwealth (2015). "Report of the Commonwealth Observer Group: Sri Lanka Presidential Election 2015."

[10]. Creswell, J. (2014). Research design: Qualitative, quantitative and mixed methods approaches (4th ed.). Thousand Oaks, CA: SAGE Publications.

[11]. European Union Election Observation Mission (2018). Final Report Republic of Kenya general elections 2017. 1-75.

[12]. Faria, C 2011, 'Gendering War and Peace in South Sudan. The Elision and Emergence of Women', The Association of Concerned Africa Scholars (ACAS), Bulletin, No. 86, pp.20-29. Fischer, 2012

[13]. Fischer, J. (2012). Electoral conflict and violence: a strategy for conflict and prevention. Washington DC: IFES

[14]. Fjelde, H. \& Kristine, H. (2016). Electoral institutions and electoral violence in sub-Saharan Africa. British Journal of Political Science 46(2): 297-320. 27(5): 818-837.

[15]. Flynn, M. "Is this Peace?" Bulletin of the Atomic Scientists. (November/December 2002). pp. 63-69.

[16]. Fodeba D. \& Sahr, F., "Disarmament, Demobilization, Rehabilitation and Reintegration (DDRR): A Case Study of Liberia, Sierra Leone and South Sudan" in New York Science Journal 3, no. 6: (2010).

[17]. Ghai, Yash and Anthony Regan "Unitary state, devolution, autonomy, secession: State building and nation building in Bougainville, Papua New Guinea" The Round Table Vol. 95, No. 386, (2006).

[18]. Gichuru, J. (2014). Participation of women in peacebuilding in Somalia: A case study of Mogadishu. International Peace Support Training Centre, Nairobi.

[19]. Golan, Galia, and Zahira Kamal. "Women's Peopleto-People Activities: Do We Do It Better?" PalestineIsrael Journal of Politics, Economics and Culture. Vol. 12/13, Issue 4/1, (2005).

[20]. Kalyvas, N. (2006). The Logic of Violence in Civil War, Cambridge University Press, Cambridge.

[21]. Kiplagat, N. (2008). 'E-discussion for the Report of the Secretary-General on Peacebuilding and Early Recovery.' 
[22]. Hart, Julie P. "Peacebuilding Through Election Assistance in Unstable Democracies: Observations from the Venezuelan Process." Peace and Change, Vol.31, No.1, (2006). pp. 75-79.

[23]. Heidi, H. (2008). "Gender and Peacebuilding and Post-Conflict Reconstruction in Africa" in The State of Africa: Post-Conflict Reconstruction and Development, eds. Dirk Kotze and Hussein Solomon (South Africa: Africa Institution of South Africa, 2008).Hilson, 2006

[24]. Mugenda, O.M \&Mugenda, A.G. (2009). Research methods: Quantitative and qualitative approaches. Acts Press: Nairobi, Kenya.

[25]. Taylor, C., Jon, P., \& Scott, S. (2017). Perils of Pluralism: Electoral Violence and Incumbency in subSaharan Africa. Journal of Peace Research 54(3): 397-411.

[26]. UNDP (2017). Elections and conflict prevention: A guide to analysis, planning, and programming. NY: Democratic Governance Group. 